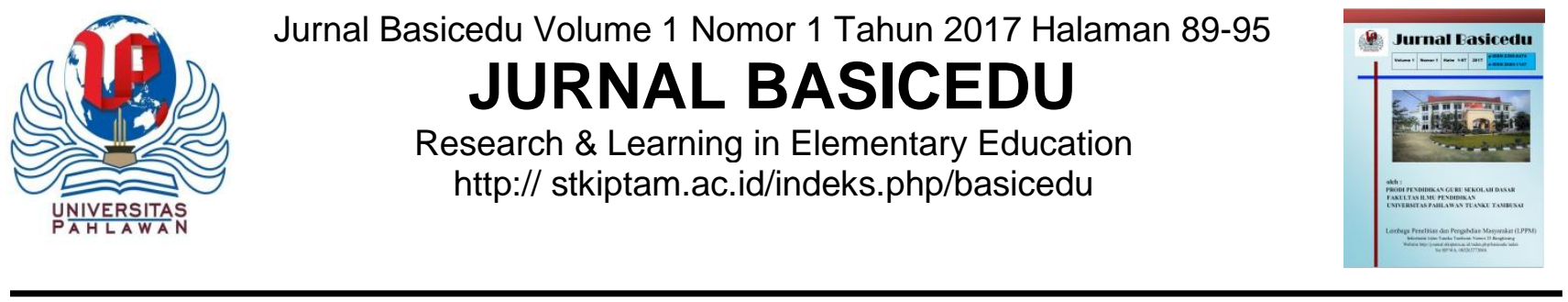

\title{
HUBUNGAN BULLYING DENGAN LINGKUNGAN, SOSIAL EKONOMI DAN PRESTASI PADA SISWA SDN 006 LANGGINI
}

\author{
Rinda Fithriyana ${ }^{1}$ \\ ${ }^{1}$ Fakultas Ilmu Kesehatan, Universitas Pahlawan Tuanku Tambusai, \\ Email : $\underline{\text { erinpku@gmail.com }}$
}

\begin{abstract}
Bullying has been recognized as a social problem, which is found among school children. Bullying behavior on the students themselves are influenced by many factors, including environmental factors, family and socioeconomics. The purpose of this study is to describe the bully, and the relationship between this behavior with environmental, economic and social behavior and academic achievement in elementary school children in the city of 006 Village Langgini Bangkinang. This study used a qualitative research approach is descriptive. The point of this study was in elementary school 006, Langgini Bangkinang City. This research was conducted in the second semester in January-February 2016. The research subject is a person or thing from which information has been obtained. Preliminary results indicate that there is a bully behaviors by fifth grade elementary school students to their friends. The boys are the bullyers, generally.
\end{abstract}

Keywords: Elementary School, Environment, Social Economy, Awards.

\begin{abstract}
Abstrak
Bullying telah dikenal sebagai masalah sosial, dimana ditemukan di kalangan anak-anak sekolah. Perilaku bullying pada siswa itu sendiri dipengaruhi oleh banyak faktor, antara lain faktor lingkungan, keluarga \& sosial ekonomi. Tujuan penelitian ini adalah untuk mengetahui gambaran bully, dan hubungan antara perilaku ini dengan masalah lingkungan, sosial ekonomi dan perilaku serta prestasi akademis pada anak SD Negeri 006 Kelurahan Langgini di kota Bangkinang. Penelitian ini menggunakan pendekatan penelitian kualitatif yang bersifat deskriptif. Adapun tempat dilakukannya penelitian ini adalah di SD Negeri 006, Kelurahan Langgini Kecamatan Bangkinang Kota, Kabupaten Kampar. Penelitian ini dilakukan pada semester genap bulan Januari-Februari 2016. Subyek penelitian merupakan seseorang atau sesuatu yang darinya diperoleh keterangan. Hasil sementara menunjukkan bahwa terdapat perilaku bully yang dilakukan oleh siswa SD kelas $V$ terhadap teman-temannya. Umumnya yang melakukan perilaku bully ini adalah anak laki-laki.
\end{abstract}

Kata kunci: Sekolah Dasar, Lingkungan, Sosial Ekonomi, Prestasi 


\section{PENDAHULUAN}

Setiap negara, menyelenggarakan pendidikan demi cita-cita nasional bangsa yang bersangkutan. Melalui proses pendidikan, suatu bangsa berusaha untuk mencapai kemajuan-kemajuan dalam berbagai bidang kehidupannya, baik dalam bidang ekonomi, sosial, politik, ilmu pengetahuan, teknologi dan dalam bidang- bidang kehidupan budaya lainnya. Melalui proses pendidikan, suatu bangsa berusaha untuk mencapai tujuan-tujuan tertentu yang direncanakan (Hasbullah, 2001).

Demikian halnya dengan bangsa Indonesia, juga menyelenggarakan pendidikan yang berdasarkan filsafat dan cita-cita nasional bangsa Indonesia yang diatur dalam Undang-Undang No. 20 Tahun 2003 tentang Sistem Pendidikan Nasional. Dalam pasal 1 ayat (1) menyebutkan bahwa pendidikan adalah usaha sadar dan terencana untuk mewujudkan suasana belajar dan proses pembelajaran agar peserta didik secara aktif mengembangkan potensi dirinya untuk memiliki kekuatan spiritual keagamaan, pengendalian diri, kepribadian, kecerdasan, akhlak mulia, serta keterampilan yang diperlukan dirinya, masyarakat, bangsa dan negara.

Pendidikan bertujuan mempersiapkan generasi muda untuk terjun dalam masyarakat dengan segala karakteristik dan kekayaan budayanya menjadi landasan dan sekaligus acuan bagi pendidikan. Oleh karena itu tujuan, isi serta proses pendidikan harus disesuaikan dengan kondisi karakteristik yaitu kekayaan dan perkembangan masyarakat tersebut. Tujuan lain yang ingin dicapai untuk mengembangkan potensi peserta didik agar menjadi manusia yang beriman dan bertakwa kepada Tuhan Yang Maha Esa, berakhlak mulia, sehat, berilmu, cakap, kreatif, mandiri dan menjadi warga negara yang demokratis serta bertanggungjawab (UU No. 20 Tahun 2003, pasal 3).
Penyelenggaraan pendidikan di Indonesia secara kelembagaan memiliki beberapa jenjang. Salah satunya adalah jenjang pendidikan dasar yang terdiri dari: Sekolah Dasar (SD) dan Madrasah Ibtidaiyah (MI), Sekolah Menengah Pertama (SMP) dan Madrasah Tsanawiyah (MTs) atau bentuk lain yang sederajat.

Sekolah dasar merupakan jenjang pendidikan paling dasar pada pendidikanformal di Indonesia yang memiliki peranan dalam keberlangsungan proses pendidikan selanjutnya.Hal ini sesuai dengan Peraturan Menteri Pendidikan Nasional No.23 Tahun 2006 yang menyatakan bahwa "Pendidikan dasar memiliki tujuan untuk meletakkan dasar kecerdasan, pengetahuan, kepribadian, akhlak mulia serta keterampilan untuk hidup mandiri dan mengikuti pendidikan lebih lanjut". Berdasarkan kutipan ini, diketahui bahwa tujuan pendidikan dasar di Indonesia adalah untuk meletakkan dasar kecerdasan, pengetahuan, kepribadian, akhlak mulia serta keterampilan pada diri masing-masing anak. Suatu yang mendasar dapat diibaratkan sebagai suatu pondasi, dimana pondasi inilah yang nantinya akan menopang dan menyokong segala sesuatu yang berada di atasnya. Melalui sekolah dasar, dasar-dasar pendidikan ditanamkan dengan benar serta diimbangi dengan pengarahan kepada anak.

Pendidikan dasar di Indonesia merupakan pondasi bagi jenjang pendidikan selanjutnya haruslah berperan dalam membentuk suatu pondasi yang kokoh berkaitan dengan watak serta kepribadian anak khususnya peserta didik. Namun apabila pondasi dalam meletakkan dasar-dasar pendidikan yang berdampak pada pembentukan watak serta kepribadian anak tidak kuat, nantinya anak akan mudah terpengaruh dengan halhal negatif. 
Selain dari sekolah, perilaku serta akhlak anak-anak juga dipengaruhi dari faktor lingkungan si luar sekolah. Baik itu faktor dari lingkungan keluarga maupun faktor dari lingkungan sekitarnya atau lingkungan masyarakat sekitarnya.

Menurut $\mathrm{Ki}$ Hajar Dewantara (Dwi Siswoyo dkk, 2007), ada tiga lingkungan pendidikan yang memiliki peranan besar terhadap perilaku serta kepribadian anak yang dikenal dengan "Tripusat Pendidikan". Tripusat pendidikan meliputi: 1) Pendidikan di lingkungan keluarga, 2) Pendidikan di lingkungan sekolah, dan 3) Pendidikan di lingkungan masyarakat. Lingkungan memiliki peran penting dalam mewujudkan kepribadian anak, khususnya lingkungan keluarga. Keluarga merupakan lingkungan sosial pertama yang dikenal oleh anak. Peran lingkungan keluarga dalam mewujudkan kepribadian seseorang, baik lingkungan pra kelahiran maupun pasca kelahiran adalah masalah yang tidak bisa dipungkiri khususnya lingkungan keluarga. Lingkungan keluarga adalah sebuah basis awal kehidupan bagi setiap manusia. Pentingnya pengaruh keluarga dalam pendidikan anak dalam beberapa masalah seperti budaya, norma, emosional dan sebagainya.

Lingkungan jika dihadapkan dengan genetik adalah faktor luar yang berpengaruh dalam pembentukan dan perubahan kepribadian seseorang baik faktor-faktor lingkungan pra kelahiran maupun pasca kelahiran yang mencakup lingkungan alam, lingkungan ekonomi, dan lingkungan social. Lingkungan sosial mencakup lingkungan keluarga, sekolah, mazhab dan sebagainya. Lingkungan social manusia adalah faktor penting dalam pembentukan kejiwaan dan norma social seseorang dalam masyarakat. Sekolah merupakan lingkungan kedua dimana anak berinteraksi dengan warga sekolah (kepala sekolah, guruguru, karyawan sekolah, dan siswa lain) dan mengembangkan kemampuannya. Perlu diketahui bahwa interaksi yang dilakukan oleh anak di sekolah mengandung muatan nilai serta aspekaspek sosiomoral. Di dalam proses interaksi tersebuttidak hanya berkenaan dengan pendidikan kognisi anak melainkan berkenaan dengan perkembangan aspek-aspek pribadi lainnya.

Pengarahan dari lingkungan terhadap perilaku anak yang berjalan dari waktu ke waktu secara terus-menerus tentu akan membentuk kepribadian anak. Lingkungan pendidikan dapat dikatakan berhasil jika lingkungan pendidikan tersebut mampu merubah tingkah laku anak baik dari segi kognitif, psikomotorik, hingga afektif anak ke arah yang lebih baik (Abu Ahmadi, 2007).

Sehubungan dengan tugas dan peranan guru dalam mendidik siswa, maka guru diharapkan dapat menciptakan iklim kondusif atau kondisi kelas yang dapat memfasilitasi siswa dalam mencapai tujuan belajarnya dan tugas perkembangannya. Hal tersebut tidak secara otomatis dapat terwujud karena banyaknya permasalahan yang menghinggapi dunia pendidikan itu sendiri, diantaranya adalah fasilitas sekolah dan perilaku siswa. Permasalahan mengenai fasilitas sekolah, misalnya: banyaknya bangunan sekolah yang rusak bahkan roboh dan minimnya alat peraga pendidikan maupun sarana penunjang yang lain. Selain itu, terjadi permasalahan pada perilaku siswa, misalnya: perilaku mencontek saat ujian, perkelahian (tawuran) antar pelajar yang berakibat pada kematian. Salah satu masalah yang berkembang di sekolah adalah perilaku bullying pada siswa.

Bullying adalah sebuah situasi dimana terjadinya penyalahgunaan kekuatan atau kekuasaan yang dilakukan oleh seseorang atau kelompok, (Sejiwa, 2008). Menurut Olweus (dalam Siswati 
dan Widayanti, 2009), bullying adalah perilaku negatif yang mengakibatkan seseorang dalam keadaan tidak nyaman/terluka dan biasanya terjadi berulang-ulang (repeated during successive encounters). Tindakan bullying sebenarnya bisa terjadi dimana saja, baik di sekolah,di rumah, maupun dilingkungan sekitar.

Perilaku bullying memiliki bentuk berbeda-beda, menurut Sejiwa (2008), perilaku yang dapat dikategorikan bullying adalah:

a. Fisik. Ini adalah jenis bullying yang kasat mata siapapun bisa melihatnya karena terjadi sentuhan fisik antar pelaku bullying dan korbannya. Misalnya: menampar, menimpuk, menjengal, meludahi, memalak, dan melempar dengan barang.

b. Verbal. Ini adalah jenis bullying yang juga bisa terdeksi karena bisa tertanggkap indra pendengaran. Misalnya: memaki, menghina, menjuluki, menuduh, menyebar gosip, memfitnah, mempermalukan di depan umum, dan menolak.

c. Psikologis. Ini jenis bullying yang paling berbahaya karena tidak tertanggkap mata atau telinga jika tidak cukup awas mendeteksinya. Peraktek bullying ini terjadi diamdiam dan di luar radar pemantauan. Misalnya: memandang sinis, mendiamkan, mengucilkan, mempermalukan, melototi dan mencibir.

Adapun karakter pada bullying menurut Sejiwa (2008), antara lain:

a. Pelaku bullying. Inilah aktor utama pelaku bullying. Pelaku bullying umumnya adalah seorang anak atau murid yang berfisik besar dan kuat. Seseorang yang memiliki kekuatan dan kekuasaan di atas korbannya. Pelaku bullying umumnya temperamental dan suka melakukan bullying terhadap orang lain sebagai pelampiasan kekesalan dan kekecewaan.

b. Korban bullying. Biasanya korban bullying memiliki ciri-ciri, antara lain, berfisik kecil, lemah, sulit bergaul, dan siswa yang rendah kepercayaan dirinya. Pelaku bullying biasanya dengan mudah mengendus calon korbannya. Korban bullying bukanlah sekedar pelaku pasif dari situasi bullying. Rata-rata korban bullying tidak pernah melaporkan kepada orang tua dan guru bahwa telah dianiaya atau ditindas anak lain di sekolahnya.

c. Saksi bullying. Para saksi bullying berperan serta dengan dua cara, antara lain: aktif menyoraki (mendukung pelaku bullying) atau diam (bersikap acuh tak acuh).

Wiyani (2012) mengungkapkan tindakan bullying cenderung disepelekan atau kurang diperhatikan dalam kehidupan sehari-hari. Masih banyak yang menganggap bahwa bullying tidak berbahaya, padahal sebenarnya bullying dapat memberikan dampak negatif bagi korbannya. Bullying memberikan dampak negatif terhadap pelaku dan korban. Dampak terbesar dialami oleh korban bullying.

Perilaku bullying yang sering ditunjukkan siswa SD diantaranya adalah perilaku meminta dengan paksa siswa yang kuat pada siswa yang lemah, seperti meminta uang, menyontek, tindakan fisik ringan yang sering dilakukan seperti memukul, mengejek atau memanggil dengan julukan yang tidak pantas dilakukan oleh siswa yang kuat terhadap siswa yang lemah, serta ancaman kepada korban yang tidak menuruti perintah dari pelaku bullying.

Salah satu kasus kematian akibat perilaku bullying adalah kematian FK, anak usia 13 tahun dengan cara bunuh diri pada 15 Juli 2005. Kematian siswi sekolah dasar ini, dipicu oleh rasa minder dan frustrasi karena sering 
diejek sebagai anak tukang bubur oleh teman-teman sekolahnya (Siswati dan Widayanti, 2009).

Tujuan penelitian ini adalah untuk mengetahui gambaran bullying, pemahaman siswa terhadap bullying, dan hubungan antara perilaku ini dengan masalah sosial ekonomi dan perilaku serta prestasi akademis pada anak SD Negeri 006 Langgini di Kota Bangkinang.

\section{METODOLOGI PENELITIAN}

1. Model pembelajaran Inkuiri adalah suatu Pendekatan Penelitian

Dalam penelitian ini, peneliti menggunakan pendekatan penelitian kualitatif yang bersifat deskriptif. Lexy J. Moleong (2007), menyatakan bahwa penilitian kualitatif merupakan penelitian yang bermaksud untuk memahami fenomena tentang apa yang dialami oleh subyek penelitian yang berupa perilaku, persepsi, motivasi, tindakan, secara holistik, yang dilakukan dengan cara deskripsi dalam bentuk kata-kata dan bahasa, pada suatu konteks khusus yang alamiah dan dengan memanfaatkan berbagai metode alamiah.

2. Tempat Peneltian

Adapun tempat dilakukannya penelitian ini adalah di SD Negeri 006, Kelurahan Langgini Kecamatan Bangkinang Kota, Kabupaten Kampar.

3. Waktu Penelitian

Penelitian ini dilakukan pada semester genap bulan Januari-Februari 2016.

4. Subyek Penelitian

Subyek penelitian merupakan seseorang atau sesuatu yang darinya diperoleh keterangan. Dalam penelitian kualitatif, subyek penelitian disebut informan. Pada penelitian ini, peneliti mengambil subyek utama penelitian yaitu siswa pelaku bullying dan siswa korban bullying di kelas V SD Negeri 006 Langgini.

5. Teknik Pengumpulan Data

Adapun teknik pengumpulan data yang dilakukan adalah dengan cara observasi, wawancara dan dokumentasi.

\section{HASIL DAN PEMBAHASAN}

Penelitian ini dilakukan kepada siswa kelas V SD Negeri 006 Langgini yang berjumlah 84 siswa. Dari hasil wawancara dengan guru kelas, guru mata pelajaran, siswa (teman maupun korban bullying), serta observasi dan dokumentasi didapatkan data bahwa ada $14,29 \%$ siswa melakukan bullying terhadap teman-temannya. Sedangkan siswa yang sering di bully ada 35,71\%.

Adapun yang menjadi aspek Bullying adalah :

\begin{tabular}{|c|c|c|}
\hline $\begin{array}{c}\text { Aspek } \\
\text { Fisik }\end{array}$ & $\begin{array}{l}\text { Aspek } \\
\text { Verbal }\end{array}$ & $\begin{array}{c}\text { Aspek } \\
\text { Psikologi }\end{array}$ \\
\hline $\begin{array}{l}- \\
\text { Menamp } \\
\text { ar } \\
- \\
\text { Menjega } \\
1 \\
- \\
\text { Meludah } \\
\text { i } \\
- \\
\text { Memala } \\
\text { k } \\
- \\
\text { Melemp } \\
\text { ar } \\
\text { dengan } \\
\text { barang }\end{array}$ & $\begin{array}{l}\text { - } \\
\text { Memaki } \\
\text { - } \\
\text { Menghin } \\
\text { a } \\
\text { - } \\
\text { Menjulu } \\
\text { ki } \\
- \\
\text { Menudu } \\
\text { h } \\
- \\
\text { Memfitn } \\
\text { ah } \\
- \\
\text { Menola } \\
\text { k }\end{array}$ & $\begin{array}{l}\text { - } \\
\text { Memandang } \\
\text { sinis } \\
- \\
\text { Mendiamkan } \\
- \\
\text { Mengucilkan } \\
- \\
\text { Mempermalu } \\
\text { kan } \\
\text { - Melototi } \\
\text { - Mencibir } \\
\text { Merendahka } \\
\text { n }\end{array}$ \\
\hline $\begin{array}{l}\text { Setelal } \\
\text { dan bukt } \\
\text { terjadi d }\end{array}$ & eneliti & $\begin{array}{l}\text { ngumpulkan } \\
\text { aku bullying } \\
6 \text { Langgini, } \\
\text { ukan lebih } \\
\text { yaitu } 80 \% \text {. }\end{array}$ \\
\hline
\end{tabular}


oleh siswa yang berbadan lebih besar dari teman sekelasnya dan juga yang ekonomi keluarganya menengah keatas. Sedangakan yang jadi korban bully adalah siswa yang dianggap lemah atau yang pendiam.

Dalam penelitian ini korban bullying tidak seluruhnya dengan alasan ekonomi lemah. Kebanyakan ditujukan kepada siswa yang dianggap tidak mampu mengimbangi dalam adu kekuatan fisik. Korban bullying ini juga sering dialami oleh guru. Hal yang sering dilakukan kepada guru adalah dengan berteriak atau menyoraki. Perbuatan bullying ini dilakukan saat mata pelajaran berlangsung maupun jam istirahat.

\section{PEMBAHASAN}

Adapun faktor-faktor yang memicu bullying dijabarkan sebagai berikut:

1. Keluarga

Lingkungan keluarga yang melakukan bullying terdiri dari anak yang orang tuanya kategori mampu, dan biasanya keluarga menuruti seluruh keinginan anak.

2. Lingkungan pergaulan

Lingkungan di sekitar rumah dimana dia melakukan interaksi sosial, bermain dan berkembang sering terjadi pertengkaran. Keluarga satu dengan keluarga yang lain saling menyerang baik secara verbal maupun non verbal.

3. Tayangan atau media

Tayangan televisi yang ditonton anak lebih sering mengandung unsur kekerasan didalamnya.

4. Iklim di sekolah

Terkadang guru kurang cepat tanggap serta kurang tegas terhadap anak yang melakukan bullying.

Secara umum, prestasi akademis subyek yang terlibat bullying adalah anak-anak yang mempunyai prestasi biasa-biasa saja di kelas.

Banyak siswa yang enggan melaporkan bullyingyang dialaminya kepada guru. Hal ini dikarenakan adanya ancaman dari pelaku bullying itu sendiri. Selain itu juga mayoritas guru menganggap bullying merupakan hal yang lumrah terjadi dalam interaksi antar anak saat bermain dan bagian dari proses pendewasaan diri seorang anak. Mereka tidak menganggap bullying sebagai perilaku yang bertentangan dengan norma sosial.

\section{SIMPULAN}

Berdasarkan hasil penelitian dan pembahasan sebelumnya, MAKA dapat disimpulkan sebagai berikut:

1. Bullying yang terjadi sekolah berdampak negatif terhadap perkembangan anak.

2. Tidak adanya hubungan antara tindakan bullying dengan prestasi belajar anak korban bullying pada tingkat Sekolah Dasar.

3. Pelaku bullying merupakan siswa yang memiliki kekuatan baik fisik ataupun sosial yang lebih dibanding teman yang lain, memiliki tempramen tinggi, dan rasa empati yang rendah.

4. kebanyakan dari korban bullying tunduk kepada perintah pelaku dan tidak berani melapor pada guru.

5. Tayangan yang sering dinikmati oleh pelaku di dalamnya banyak mengandung unsur-unsur kekerasan sehingga mempengaruhi perilaku si anak.

\section{UCAPAN TERIMA KASIH}

Ucapan terima kasih peneliti sampaikan kepada keluarga, sekolah, dan juga institusi yang sudah membantu dalam dalam pelaksanaan penelitian ini.

\section{DAFTAR PUSTAKA}

Afida, H. (2007). Pengaruh kebiasaan belajar dan minat membaca terhadap prestasi belajar siswa kelas VIII pada materi 
pelajaran IPS di MTs Darul huda Wonodadi Blitar. Skripsi.

Alika, H.I. (2012). Bullying as a correlate of dropout from school among adolenscent Education. Vol. 1322 No. 3.

Arikunto, S. (2002). Prosedur penelitian. Cetakan keduabelas. Jakarta: PT. Rineka Cipta.

Azwar, (1998). Metodelogi Penelitian, Yogyakarta: Pustaka Pelajar Offset.

Azwar, S. (2002). Penyusunan skala psikologi. Yogyakarta: Pustaka pelajar.

Coloraso, JP. (2000). Penindas, tertindas, dan penonton. Resep memutus rantai kekerasan Anak dari Prasekolah Hingga SMU, jakarta: Serambi.

Christin, (2009). Dampak psikologi bullying pada siswa SMA. Yogyakarta: Gunadarma University.

Djuwita, R. 2006. "Kekerasan Tersembunyi di Sekolah": Aspek-aspek Psikososial dari Bullying. Dari www.didplb.or.id.

Down, F. (2012). Stop bullying dan atribut aneh pada MOS (Masa Orientasi Siswa), Kompasiana.com

Gifron, Rivara, \& Freudtner. (2000). Children hurting children. Pediatricts Review.

Gunarsa, DS, dan Gunarsa, Ny. DS. (1989).

Perkembangan Anak Dan Remaja. Jakarta: Gunung Mulia.

Hasbullah, (2001). Dasar-dasar Ilmu Pendidikan. Jakarta: PT. Raja Grafindo

Persada.

Huraerah, A. (2007). Child Abuse (Kekerasan terhadap Anak). Bandung: Nuansa. Kartono, K. (2000.) Psikologi Abnormal
Dan Abnormalitas Seksual. Bandung: Mandar Maju.

Krahe, B. 2005. Perilaku Agresif: Buku Panduan Psikologi Sosial. Yogyakarta: Pustaka Pelajar.

Meichati, S. (1983). Kesehatan Mental. Yogyakarta: Fakultas Psikologi UGM.

Mudjijanti, F. (2011). School Bullying dan Peran Guru dalam Mengatasinya.

Naskah Krida Rakyat. 12 Desember 2011.

Yoewono, S. (2008). Karakteristik Pembelajaran di Sekolah Dasar. Wahana Sekolah Dasar. Tahun 16, Nomor 2, Juli 200 
